\title{
Khazanah
}

\author{
GROTIUS \\ DOI: https://doi.org/10.22304/pjih.v4n1.a12
}

Hugo de Groot atau yang lebih dikenal dengan Grotius adalah tokoh pemikir Belanda kaliber internasional dengan segudang karya monumental yang bukan saja menjadi rujukan masyarakat internasional, tapi juga memberikan pengaruh mendalam dan relatif abadi dalam sejarah dunia. Grotius adalah tokoh dengan multi wajah dan wijhah (orientasi) keilmuan. Dia adalah ahli sejarah, ahli hukum, filosof, diplomat, dan juga praktisi hukum. Dari sekian banyak pengakuan dan julukan yang diterima Grotius adalah kepakarannya dalam hukum internasional sehingga dunia mengakuinya sebagai Bapak Hukum Internasional Modern khususnya lewat magnum opus nya, De Jure Belli ac Pacis.

Buku "De Jure Belli ac Pacis" adalah karya yang masuk daftar karya klasik dunia (universal classic) yang substansinya tidak didasarkan kepada keahlian yang lazim dalam sebuah karya klasik. Dalam buku ini Grotius menyajikan pikiran dan ideidenya lewat retorika yang keluar dari arus utama yang cenderung monoton dan membosankan, juga berhasil mengurai kompleksitas persoalan yang nyaris tanpa solusi dengan jalan keluar yang berbasis rasionalitas canggih. Oleh karenanya tidak aneh apabila karya Grotius ini diakui sebagai tulisan yang sangat bermutu dan elegan.

Meskipun diakui mengandung beberapa kelemahan, namun karya Grotius ini diakui sebagai karya jenius yang terekam abadi dalam lipatan sejarah manusia berabad-abad. Tampil sebagai ilustrasi kemajuan peradaban manusia dan merupakan warisan yang sangat berharga. Karya Grotius ini bukan literatur dalam pengertian teknis, tapi lebih tinggi dari itu. Sebuah kemenangan kecerdasan atas dominasi irasionalitas dan kecenderungan peradaban nir etik. Publikasinya menandai sebuah era dalam sejarah bangsa-bangsa ketika mengalami peradaban chaotic tanpa hukum dan nalar, ia berhasil menciptakan sebuah sistem yang mencerahkan untuk menerangi jalan penguasa dan masyarakat agar berada di jalan damai dan kerukunan antar bangsa yang abadi.

\section{Sketsa Biografis}

Grotius, atau Hugo de Groot yang dalam bahasa Latin dikenal dengan nama Huig de Groot lahir di kota Delft, Belanda, pada tanggal 10 April $1583 .{ }^{1}$ Grotius memulai pendidikannya di Universitas Leiden pada tahun 1594 pada usia sebelas tahun

PADJADJARAN Jurnal IImu Hukum Volume 4 Nomor 1 Tahun 2017 [ISSN 2460-1543] [e-ISSN 2442-9325]

1 Renee Jeffery, Hugo Grotius in International Thought, New York: Palgrave, 2006, hlm. 3. 
sehingga ia dijuluki sebagai anak yang dewasa sebelum waktunya (precocious). Karena kecerdasannya, Grotius kemudian menjadi murid dari para ilmuwan terkenal dari Belanda, juga ilmuwan Prancis kenamaan J.J.Scaliger, sejarawan Belanda Justus Lipsius, dan ahli matematika Simon Stevin. ${ }^{2}$ Berbeda dengan anggapan masyarakat pada umumnya yang menganggap Grotius hanya menekuni bidang hukum, faktanya dia meminati banyak cabang ilmu yang ditawarkan di universitas. Di didik dalam tradisi pendidikan yang humanis memberikan pengaruh khusus kepada Grotius yang membawanya menjadi sosok sastrawan Latin dan juga ahli sejarah kenamaan. ${ }^{3}$

Grotius lulus dari Universitas Leiden pada tahun 1597 kemudian bergabung dengan Justin van Nasau dan Johan van Oldenbarnevelt dalam suatu misi diplomatik ke Prancis yang bertujuan untuk mencegah Prancis melakukan perjanjian perdamaian dengan Spanyol, karena Belanda terlibat perang untuk memerdekakan diri dari Spanyol. Meskipun demikian, Grotius tidak memainkan peran diplomatik resmi, hanya mendampingi gurunya Oldenbarnevelt. ${ }^{4}$ Meskipun misi diplomatik tersebut tidak sepenuhnya sukses, namun sangat berarti bagi Grotius, karena dia mendapat pujian dari Raja sebagai "the miracle of Holland". Yang lebih penting, satu tahun kemudian Grotius dianugerahi doktor ilmu hukum dari University of Orleans yang dikemudian hari akan menjadi modal penting atas kontribusinya dalam sejarah pertumbuhan hukum internasional.

Pada tahun 1601 Grotius mulai berkarir sebagai sejarawan yang antara lain menulis mengenai legitimasi perjuangan kemerdekaan Belanda dari Pemerintah Spanyol yang dituangkan dalam bukunya De Antiquitate Reipublicae Batavicae (The Antiquity of the Batavian Republic). Tiga tahun kemudian (1604) ketika usianya menginjak 23 tahun, Grotius membuka kantor hukum dan salah satu klien utamanya adalah Dutch East India Company. Sebagai praktisi hukum Grotius terlibat dalam penyelesaian sengketa hukum antara Portugis dan Belanda dalam masalah perdagangan di Selat Malaka pada tahun 1602. Buah dari keterlibatannya, Grotius kemudian menulis buku dengan judul De Jure Praedae (Rampasan yang legal). Meskipun buku tersebut tidak tuntas namun berisi argumentasi hukum Grotius dalam kasus tersebut. Tanpa alasan yang jelas, Grotius tidak pernah menerbitkan buku tersebut. Manuskrip tersebut kemudian ditemukan di sebuah pelelangan pada tahun 1864. Salah satu bagian penting dari manuskrip tersebut adalah bab yang membahas mengenai konsep Mare Liberum (Laut Bebas) yang berisi argumentasi hukum untuk mempertahankan hak berdagang Dutch East India

2 Charles Edwards, Hugo Grotius the Miracle of Holland: A Study in Political and Legal Thought, Chicago: NelsonHall, 1981, hlm. 2; R.W. R.W. Lee, Hugo Grotius, Annual Lecture on a Mastermind, Henriette Hertz Trust of the British Academy 1930, London: Humphrey Milford, 1930, hlm. 5.

3 Richard Tuck, Introduction to The Rights of War and Peace, Indianapolis: Liberty Fund, 2005, hlm. xiii. 
Company dalam negosiasi 11 tahun gencatan senjata antara Spanyol dan Belanda pada tahun $1609 .^{5}$

Mare Liberum mendapat respon serius dari kalangan ilmuwan. Pada tahun 1612 buku tersebut ditempatkan dalam daftar buku terlarang oleh lembaga Inkuisisi Spanyol (Spanish Inquisition) dan pada tahun 1625 para ilmuwan Portugis di Universitas Valladolid yang dipimpin oleh Guru Besar Hukum Kanonik Serafim de Freitas menerbitkan buku dengan judul De justo imperio Lusitanorum Asiatico sebagai bantahan terhadap Mare Liberum. Yang paling masyhur adalah bantahan dari ilmuwan Inggris, John Selden yang mempublikasikan bukunya pada tahun 1636 dengan judul provokatif dan menantang, Mare Clausum. ${ }^{6}$ Perdebatan panas antara Grotius dan Selden, antara Mare Liberum versus Mare Clausum ini masyhur dengan istilah 'Battle of the Book'.

Sebagai seorang Teolog, pada tahun 1611 Grotius menerbitkan buku dengan judul Meletius sive de iis quae inter Christianos conveniunt epistola (Meletius or Letter on the Points of Agreement between Christians) yang berisi gagasan mengenai persatuan Kristen. Buku teologi berikutnya diterbitkan tahun 1617 dengan judul Defensio Fidei Catholicae de Satisfactione (A Defence of the Catholic Faith Concerning the Satisfaction of Christ, Against Faustus Socinus). Karya tersebut melibatkan Grotius pada pemikiran kontroversial mengenai keagamaan pada waktu itu.

Grotius dan rekannya sekaligus juga gurunya Johan van Oldenbarnevelt ditangkap pada tanggal 29 Agustus tahun 1618 atas laporan lawan politiknya untuk suatu kesalahan yang tidak jelas. Namun penahanan ini menjadi berkah tersendiri bagi Grotius, karena selama di penjara dia dapat menuntaskan beberapa karya tulisnya antara lain De Veritate Religionis Christianiae dan Inleiding tot de Hollandsche Rechtsgeleertheyd (Introduction to the Jurisprudence of Holland). Karya tulis lainnya yang diselesaikan adalah De Jure Belli ac Pacis yang mulai ditulis pada tahun 1622 dan dipublikasikan pada tahun 1625. Buku ini merupakan magnum opus dari Grotius dan menjadi identik dengan dirinya. Penulisan buku ini dimotivasi oleh situasi sosial politik yang penuh gejolak ketika itu dan kerusakan akibat Perang Tiga Puluh Tahun. ${ }^{7}$ Grotius meninggal dunia pada tanggal 28 Agustus 1645 pada usia 62 tahun dan dimakamkan di kota Delft.

4 Martin van Gelderen, Introduction to The Dutch Revolt, Cambridge: Cambridge University Press, 1993, hlm. xxvii.

5 Hugo Grotius, Mare Liberum (The Free Sea), trans. Richard Hakluyt, ed. David Armitage, Indianapolis: Liberty Fund, 2004.

6 Mónica Brito Vieira, "Mare Liberum vs. Mare Clausum: Grotius, Freitas, and Selden's Debate on Dominion over the Seas," Journal of the History of Ideas, Vol. 64, No.3, 2003, hIm. 361-77.

7 Yasuaki Onuma, Introduction to A Normative Approach to War: Peace, War and Justice in Hugo Grotius, Oxford: Clarendon Press, 1993, hlm. 8. 


\section{Sekulerisasi Hukum Alam}

Secara tradisional, hukum alam pada umumnya dinisbahkan kepada hukum Tuhan atau hukum agama (...to link reason with some notion of a deity). ${ }^{8}$ Hukum alam dimaknai sebagai hukum yang lebih tinggi (higher law) yang memiliki karakteristik universal dan itu tidak lain adalah hukum Tuhan. Hukum alam adalah hukum yang berisi kehendak Tuhan (divine will). ${ }^{9}$ Salah satu proponen utamanya adalah Thomas Aquinas yang kemudian mempopulerkan mazhab Thomism. ${ }^{10}$ Proponen lainnya adalah John Salisbury, Dante Alighieri, Piere Dubois, Marsilius Padua, John Wyclliffe dan Johannes Huss. Bagi kaum Thomisms, hukum alam adalah hukum yang bersumber dari sesuatu yang berada di luar nalar (irasional). Grotius kemudian mengoreksi paham ini dengan melepaskan hukum alam dari unsur-unsur teologis. Sumber hukum alam adalah rasionalitas manusia. Dengan perkataan lain, Grotius melakukan sekulerisasi hukum alam. Hal ini dilakukan Grotius sebagai bagian dari reformasi di kawasan Eropa Utara dengan menumpang reformasi gereja yang dilakukan oleh kaum Kristen Protestan.

Dengan pola pikir yang menolak teologi Katolik Roma dan juga menolak paham hukum alam ala kaum Thomist, Grotius lebih memilih nalar (akal budi manusia) sebagai sumber hukum alam dengan meminjam konsep Plato mengenai nalar sosial umat manusia (social nature of humankind). Dalam konteks ini eksistensi hukum alam dipahami sebagai perwujudan dari akal budi manusia, yaitu kehendak untuk hidup bersama dalam masyarakat. Jadi, menurut Grotius yang alami itu (nature) sekaligus juga yang rasional itu adalah keinginan manusia untuk hidup di masyarakat. Maka, hukum alam menurut Grotius adalah hukum yang berbasis kepada akal budi manusia.

Namun, Grotius memaknai nalar sosial ini lebih luas dari pemaknaan Plato. Menurut Grotius, nalar sosial ini bukan sebatas kehendak untuk hidup di masyarakat, tetapi juga kehendak untuk hidup dalam suatu masyarakat yang damai dan tertib (peaceful and well-ordered society). Jadi, nalar sosial tersebut bukan saja prasyarat untuk terjaganya tertib sosial, melainkan juga menjadi sumber dari segala bentuk hukum (source of all law properly so-called). Atas dasar ini, Grotius mendalilkan bahwa, "natural law is so immutable that it cannot be changed by God Himself".

Hukum alam yang sudah tersekulerkan menurut Grotius didasarkan atas dua prinsip pokok. Pertama, secara a priori, menguji segala sesuatu dengan parameter rasionalitas dan akal budi manusia, kedua, secara a posteriori, menguji penerimaan

8 Ian McLeod, Legal Theory, UK: Palgrave Macmillan, 2005, hlm. 55.

9 Brian Bix, "Natural law Theory" dalam buku A Companion to Philosophy of Law and Legal Theory, yang disusun oleh Dennis Patterson (ed.), Oxford: Blackwell Publishers, 1999, hlm. 224-225.

10

McLeod, Op.cit., hlm. 52. 
prinsip tersebut oleh bangsa-bangsa di dunia. Menurut Grotius, hukum alam terdiri dari prinsip-prinsip mengenai nalar yang benar (right reason) yang mengantarkan kita untuk mengetahui bahwa suatu perbuatan itu secara moral benar atau salah atas dasar kesepakatan atau ketidaksepakatan dengan pertimbangan rasional dan nalar sosial. Hukum alam dapat ditemukan (discoverable) dengan nalar manusia. Menurut nalar hukum alam yang tersekulerkan (seculerized natural law) ala Grotius, benar dan salah tergantung kepada hakikat atau nalar tentang sesuatu, bukan karena firman Tuhan (decre of Good). ${ }^{11}$ Dalam konteks ini Ian McLeod mengatakan sebagai berikut, "...by delivering an account of natural law devoid of the taint of Propery, Grotius made it possible for people to subscribe to its tenets, irrespective of the nature, or even the existence, of their personal religious beliefs". ${ }^{12}$ Beberapa contoh prinsip hukum alam yang berbasis kepada nalar sekulernya Grotius antara lain, Pacta sunt servanda (perjanjian harus dihormati), menghormati hak milik orang lain, pembayaran kompensasi atas kerugian yang ditimbulkan. Prinsip-prinisp tersebut terlahir dari nalar sosial manusia, demikian kata Grotius.

Dalam bukunya yang dipublikasikan lebih awal, De Jure Praedae, Grotius mengemukakan prinsip pokok ajarannya tentang hukum alam sebagai sesuatu yang bersumber dari Tuhan sebagai pencipta alam semesta. Namun, pergeseran ke arah sekulerisasi hukum alam mulai terlihat dalam magnum opus nya, De Jure Belli ac Pacis yang mendefinisikan hukum alam bukan sebagai divine will, melainkan, "...the Rule and Dictate of Right Reason, shewing the Moral Deformity or Moral Necessity there is in any Act, according to its Suitableness or Unsuitableness to a reasonable Nature". Konsekuensinya, kata Grotius, suatu perbuatan dinilai baik atau buruk bukan oleh Tuhan sang Pencipta semesta, melainkan oleh rasionalitas alamiah (reasonable nature)..$^{13}$ Dalam hal ini Grotius menegaskan bahwa prinsip hukum alam tersebut memiliki suatu validitas intrinsik dan dapat dipahami sebagai sebuah upaya untuk mewujudkan suatu tatanan moral universal yang sebenarnya di tengah perpecahan institusi dan paham keagamaan (Kristen) pada saat itu. ${ }^{14} \mathrm{Hal}$ ini tentu saja berkaitan dengan semakin menyusutnya pengaruh dogma ajaran Kristen.

Sekulerisasi hukum alam ala Grotius menurut Jean Barbeyrac berbasis kepada apa yang oleh Grotius disebut sebagai etiamsi daremus atau disebut juga sebagai hipotesis non-theistik (impious hypothesis). Hipotesis ini sebetulnya digunakan oleh Grotius sebagai basis filosofis dalam pengembangan teori hukum internasional. Ada dua arus utama terkait dengan interpretasi seputar sekularisasi hukum alam yang berbasis kepada hipotesis non-theistik. Menurut penafsiran konventional (standard

\footnotetext{
11 Hari Chand, Modern Jurisprudence, Kuala Lumpur: International Law Book Series, 2005, hlm. 41.

12 McLeod, Op.cit., hlm. 56.

13 Jeffery, Op.cit., hlm. 36.

14 E.B.F. Midgley, The Natural Law Tradition and the Theory of International Relations, New York: Harper \& Row, 1975, hlm. 141.
} 
or orthodox interpretation), sekulerisasi hukum alam dilakukan oleh Grotius lebih ditujukan sebagai emansipasi ilmu hukum (emancipation of jurisprudence) khususnya hukum internasional dari dominasi teologi, khususnya dominasi interpretasi kaum gereja dan para teolog Kristen. Sedangkan menurut tafsir kaum revisionist, teori hukum alam Grotius itu bukan dan tidak mengarah kepada sekulerisasi hukum alam, karena Grotius masih mempertahankan premis-premis Ketuhanan di dalam doktrin-doktrinnya. Dalam hal ini Grotius mengatakan sebagai berikut: "God, as being our Creator, and to whom we owe our Being, and all that we have, ought to be obeyed by us in all things without Exception, especially since he has so many Ways shewn his infinite Goodness and Almighty Power". Pernyataan ini mengindikasikan bahwa hipotesis non-theistik hanya sekedar sarana hipotetis yang digunakan untuk menyambungkan tata laku atau moralitas yang berbasis kepada ajaran Kristen dengan yang berbasis kepada nalar manusia. ${ }^{15}$

Dengan menetapkan prinsip bahwa hukum alam itu tetap berlaku, meskipun tanpa kehadiran Tuhan, Grotius sebenarnya ingin menghilangkan dominasi doktrin Kristen, sehingga masyarakat di luar penganut Kristen dapat mengikuti dan menaati hukum khususnya hukum perang dan damai yang dia perjuangkan ketika itu. Menurut Ernest Troeltsch, Grotius secara eksplisit menegaskan hubungan antara teorinya dengan dominasi Calvinism dan berusaha untuk mengganti sistem negara Gereja Calvinistic yang mendominasi kehidupan politik dan agama di Belanda yang menyebabkan negara tersebut menjadi terpecah, dengan kebijakan yang lebih toleran yang berbasis kepada rasionalitas dan motivasi-motivasi politik. ${ }^{16}$ Dengan demikian, hipotesis non-theistik itu tidak ada kaitannya dengan sekulerisasi hukum alam, melainkan untuk menegaskan bahwa hukum alam itu bukan dan tidak berkaitan dengan kehendak yang sewenang-wenang (arbitray will) atau Kehendak Tuhan (Divine Will). Hukum alam adalah suatu sistem hukum abadi (immutable system) yang memiliki otonomi dan indepedensi tersendiri untuk menentukan validitas normatifnya. ${ }^{17} \mathrm{Hal}$ ini dikonfirmasi oleh Grotius yang mengatakan bahwa, "...not even God can change the law of nature".

\section{Ius Gentium}

Ius gentium adalah istilah paling tua yang digunakan untuk merujuk kepada apa yang sekarang dikenal dengan hukum internasional. Para sejarawan mencatat bahwa istilah tersebut pertama kali digunakan oleh ahli hukum Romawi kenamaan, Markus Tullius Cicero (106-43 B.C.). Oleh karenanya Cicero diakui dan dikenal sebagai Bapak Hukum Bangsa-Bangsa (Father of the Ius Gentium). Ius gentium

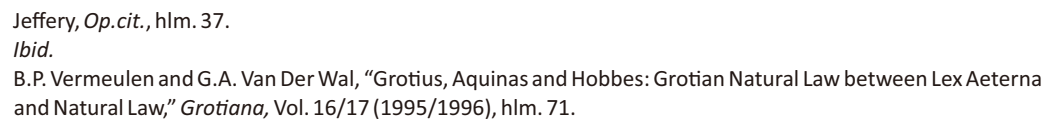


dimaksudkan sebagai perwujudan hukum alam dalam realitas kehidupan manusia. $\mathrm{Hal}$ ini bisa dilihat dari pernyataan Cicero ketika menjelaskan relasi antara lex naturae dan ius gentium sebagai berikut: "...what is accepted by all peoples is to be held as natural law". Oleh karenanya ius gentium dan ius naturale sebenarnya adalah sinonim, karena keduanya berasal dari nalar alamiah (ratio naturalis).

Terilhami oleh esensi dari ius gentium, Grotius mengangkat sistem hukum alam untuk menjadi tertib hukum bangsa-bangsa (ius gentium primarium). Secara specific Grotius mengatakan; "what the common consent of mankind has shown to be the will of all, that is law."18 Grotius kemudian mensistematisasi ius gentium menjadi hukum internasional modern lewat karyanya De lure Belli ac Pacis (Hukum Perang dan Damai) yang dipublikasikan pada tahun 1625. Grotius menawarkan hukum antar bangsa yang berbasis kepada kehendak negara (voluntary ius gentium), suatu sistem hukum positif yang berbeda dengan hukum alam. Perwujudan hukum ini adalah perjanjian (treaties) dan kebiasaan (customs) yang sangat berpengaruh terhadap masyarakat Eropa pada saat itu.

Dalam pengantar bukunya De lure Belli ac Pacis, Grotius menjelaskan dua fondasi hukum bangsa-bangsa, yaitu pertama, kebiasaan (custom) dan persetujuan (consent), dan kedua adalah "nature" (alam) baik dalam hukum positif maupun hukum alam. ${ }^{19}$ Meskipun Grotius membedakan fondasi ius gentium yang berasal dari hukum alam dan hukum positif, namun dia menegaskan bahwa berbagai macam hukum positif sebenarnya merupakan derivasi dari hukum alam. Basis hukum alam dalam ius gentium ditemukan dalam prinsip mengenai kewajiban dan persetujuan bersama. Hal inilah yang menjadikan individu terikat oleh perjanjian untuk melaksanakan kewajiban satu individu dengan yang lainnya. Oleh karena itu, menurut Grotius, hukum alam dapat dikatakan sebagai 'nenek moyang' (Great Grandmother) dari hukum domestik (municipal law) dan juga berbagai bentuk hukum positif lainnya. Namun, menurut Samuel Pufendorf, ini tidak berarti bahwa hukum bangsa-bangsa atau hukum internasional itu sebagai hukum alam yang diterapkan kepada negara-negara. Tapi, hukum alam itu adalah, pertama, sumber independen bagi hukum internasional, dan kedua, penetrasi hukum alam dianggap mendampingi elemen-elemen penting lainnya dari semua bentuk hukum. ${ }^{20}$

Dalam perkembangannya, Grotius membedakan antara hukum internasional dengan hukum alam. Perbedaan utamanya terletak pada "persetujuan bersama" (common consent). Hukum internasional mensyaratkan adanya persetujuan bersama dari negara-negara, sedangkan eksistensi hukum alam tidak memerlukan adanya persetujuan tersebut. Selengkapnya Grotius mengatakan sebagai berikut: ${ }^{21}$

\footnotetext{
18 Sebagaimana dikutip oleh Jeffery, Op.cit., hlm. 38.

19 Ibid.

20 Ibid.

21 Ibid., hlm. 39.
} 
"But as the Laws of each State respect the Benefit of that State; so amongst all or most States there might be, and in Fact there are, some Laws agreed on by common Consent, which respect the Advantage not of one Body in particular, but of all in general. And this is what is called the Law of Nations, when used in Distinction to the Law of Nature."

Mengenai kesetaraan hukum dan moral dalam konteks hukum internasional, Grotius berpendapat bahwa hukum internasional berlaku kepada negara-negara sama halnya ketika hukum tersebut juga berlaku untuk individu-individu. Jadi, ketika menuntut keadilan bagi warganegara, tapi hal yang sama tidak diberlakukan bagi pemerintah, maka hal tersebut dianggap sebagai suatu kekeliruan.

\section{Hukum alam dan hukum internasional}

Hukum internasional (ius gentium) menurut Grotius seperti halnya hukum perdata masing-masing negara adalah produk dari kehendak bukan produk alam atau nalar. Lebih lanjut Grotius menjelaskan bahwa hukum internasional adalah tata laku (code of conduct) yang mengatur interaksi negara-negara atau pemerintahan yang memberikan manfaat bagi negara-negara. Hal yang sama berlaku pula bagi hukum perdata suatu negara yang memberikan manfaat bagi negara tersebut atau warganegaranya. Kemanfaatan yang spesifik terhadap negara-negara inilah yang merupakan elemen pembeda dengan konsep hukum alam. Alih-alih menjadi komponen atau elemen dari hukum alam, hukum internasional justru merupakan tata laku normatif yang otonom (autonomous normative code) yang paling sedikit dibatasi atau terkendala oleh hukum alam.

Menurut Grotius sebagaimana dikutip Teson, ${ }^{22}$ hukum alam menempatkan dirinya sebagai penjaga moral manakala terjadi pengabaian terhadapnya. Apabila hukum internasional tidak mengatur, misalnya, apakah tawanan perang itu boleh dibunuh atau tidak, maka hukum alam akan menegaskan bahwa tawaranan perang tidak boleh dibunuh. Tapi apabila hukum internasional mengatur mengenai hal ini, maka aturan hukum internasional ini akan menggantikan aturan hukum alam. Dalam konteks ini, Grotius menjelaskan lebih lanjut bahwa hukum internasional dapat mengijinkan suatu tindakan yang sebetulnya terlarang dalam hukum alam. Misalnya, hukum internasional dapat membenarkan adanya pembunuhan terhadap tawanan perang .

Hukum internasional menurut Grotius menjamin eksistensi doktrin "solemn war" (perang yang benar mensyaratkan adanya deklarasi perang). Jadi, menurut hukum internasional, suatu peperangan dinyatakan benar (just) apabila didahului dengan deklarasi perang (solemn). Hal ini berbeda dengan hukum alam yang

22 Fernando R. Teson, “Hugo Grotius on War and the State”, http://oll.libertyfund.org/pages/Im-grotius, diakses 8 Agustus 2017. 
mengajarkan bahwa suatu peperangan dianggap sah (just) apabila dilakukan untuk melawan atau menghukum ketidakadilan alamiah (natural injustices). Terlebih lagi, hampir semua larangan perang menurut hukum alam justru dihapus dan digantikan dengan kebolehan menurut hukum internasional. Dalam konteks ini adalah sah menurut hukum bagi seorang musuh untuk melukai lawannya baik terhadap orang maupun barang.

Pandangan ini menurut Teson cukup mengkhawatirkan. ${ }^{23}$ Grotius tampaknya ingin melegalkan kebiadaban perang agar sesuai dengan hukum internasional. Tapi sebetulnya yang diinginkan oleh Grotius bukan menjadikan hukum internasional sebagai hukum yang memiliki kekuasaan preskriptif. Yang menjadi perhatian Grotius adalah menjadikan hukum internasional bagian dari hukum positif tapi bukan bagian dari hukum yang dianggap valid secara preskriptif. Dalam konteks ini terdapat dua pengertian kata "lawful" (sah secara hukum), pertama adalah yang benar-benar sah oleh dirinya sendiri, kedua yang sah secara eksternal. Hukum internasional ditolak sebagai hukum yang memiliki kekuasaan preskriptif terutama disebabkan karena tidak memiliki kekuatan mensahkan atau mem-validkan dirinya sendiri. Alasan inilah yang menyebabkan Grotius mengenyampingkan hukum internasional atas nama hukum alam. Yang lebih penting, alasan utama yang digunakan Grotius untuk mendukung pandangan terbaliknya terhadap doktrin solemn war adalah betul-betul didasarkan atas nilai hukum alam khususnya mengenai konsep equity (kesetaraan), justice (keadilan), dan reason (nalar). Jadi pada akhirnya, hak untuk memperoleh perdamaian (the right of peace) yang termasuk pula hak yang secara alamiah berbentuk perang yang benar dan cara peperangan yang benar, mengalahkan hak untuk berperang (the right of war).

\section{Just War}

Konsep just war (perang yang adil/benar) merupakan salah satu tema penting dalam magnum opus nya Grotius. Dia membedakan antara ius ad bellum (alasan perang yang benar/the rightful causes of war) dan ius in bello (tata cara perang yang benar/the rightful conduct of war). Perang menurut Grotius, bukan hanya sesuai tapi dalam hal tertentu merupakan keharusan yang dibenarkan oleh ketiga sistem hukum yaitu hukum alam, hukum internasional, dan hukum domestik. Grotius tidak menganggap bahwa perang itu diluar parameter moral dan hukum, tapi dia berpendapat bahwa perang adalah instrumen untuk pemenuhan hak. Oleh karena itu dia berpendapat bahwa apabila penyelesaian secara hukum gagal, maka perang dapat dilakukan sebagai alternatif penyelesainnya. ${ }^{24}$

\footnotetext{
23 Ibid.

24 Lihat Edward Dumbauld, Life and Legal Writings of Hugo Grotius, Norman: University of Oklahoma Press, 1969, hlm. 73.
} 
Konsep just war muncul pada tiga karya Grotius yaitu Commentarius in Theses, De Jure Praedae, dan De Jure Belli ac Pacis. Dalam buku In De Jure Praedae, Grotius menggunakan konsep just war untuk membatasi pengertian hanya pada alasanalasan yang memberikan justifikasi adanya perang. Dalam hal ini Grotius berangkat dari premis bahwa perang itu adalah suatu tindakan yang tidak mesti selalu bertentangan dengan hukum alam atau hukum Injil. ${ }^{25}$ Selengkapnya Grotius mengatakan sebagai berikut:

"God wills that we should protect ourselves, retain our hold on the necessities of life, obtain that which is our due, punish transgressors, and at the same time defend the state, executing its orders as well as the commands of its magistrates... Thus it is God's Will that certain wars should be waged; that is to say (in the phraseology of the theologians), certain wars are waged in accordance with God's good pleasure. Yet no one will deny that whatsoever God wills, is just. Therefore, some wars are just; or, in other words, it is permissible to wage war."26

Apabila alasan pembenar ditemukan, maka semua tindakan yang diperlukan untuk mencapai tujuan dapat dibenarkan, termasuk perang. Jadi alasan adalah faktor penting sahnya suatu peperangan. Secara demikian, maka perang adalah sesuatu yang dapat diterima dalam nalar hukum alam.

Pertanyaan pentingnya adalah, siapa yang memiliki wewenang untuk menyatakan perang. Ada perbedaan pendapat antara Grotius dengan tokoh pemikir lainnya semisal Thomas Aquinas. Dalam bukunya yang terbit lebih dahulu, Jure Praedae, Grotius berbeda pendapat dengan Aquinas yang mengatakan bahwa yang berwenang menyatakan perang adalah pemerintah (the authority of the ruler, by whose commands the war is to be waged). ${ }^{27}$ Sedangkan Grotius berpendapat bahwa individu atau atau pihak non-pemerintah dapat menyatakan perang (private wars are justly waged by any persons whatsoever). Jadi bagi Grotius, individu atau pihak non-pemerintah dapat melakukan perang secara privat begitu juga individu dapat bertindak atas nama negara untuk menyatakan perang yang bersifat publik. Atas dasar ini, dalam kapasitasnya sebagai pengacara the Dutch East Indie Company, Grotius berpendapat bahwa tindakan yang dilakukan oleh perusahaan tersebut sebagai suatu yang sah secara hukum. Tapi, di dalam bukunya, De Jure Belli ac Pacis, meskipun dia tetap mempertahankan konsep mengenai "private war", dia lebih menekankan bahwa kewenangan untuk menyatakan perang dan membuat perdamaian itu harus dilakukan oleh entitas yang memiliki kedaulatan, yaitu negara.

${ }_{25}$ Op.cit., hlm. 39-40.

26 Ibid.

27 Ibid. 
Dalam pengantar buku De Jure Praedae, Grotius menjelaskan bahwa empat alasan pembenar adanya perang merupakan turunan dari sembilan aturan (nine rules) dan tiga belas hukum (thirteen laws) dari hukum alam. Pertama adalah defensio sui, yaitu alasan peperangan untuk keperluan mempertahankan diri atau yang dikenal dengan istilah self-defense. Atas dasar ini perang adalah sesuatu yang dibenarkan karena bertujuan untuk mempertahankan sesuatu yang asasi yaitu mempertahankan hidup. Kedua adalah recuperation juris ac rerum ablatarum. Dengan alasan ini perang dilakukan untuk kepentingan mempertahankan hak milik (recuperation juris ac rerum ablatarum). Dalam konteks yang lebih luas tentunya alasan ini dapat diaplikasikan dalam perang dengan alasan untuk mempertahankan wilayah suatu negara. Alasan ketiga adalah damnorum et impensarum quae ex bello oriuntur repetitio. Perang dilakukan dengan alasan yang terkait dengan adanya kewajiban untuk melakukan perbaikan (reparation) oleh pihak lain dengan alasan karena adanya pengabaian baik yang bersumber dari kontrak, undang-undang, atau karena kelalaian. Terakhir adalah punitio hostium, yaitu perang dengan alasan karena kesalahan atau kerugian baik karena perkataan atau perbuatan yang disebabkan oleh niat yang tidak baik dari pihak musuh, sehingga alasan perang adalah untuk menjatuhkan hukuman (inflicting punishment). Baik De jure Praedae maupun De Jure Belli ac Pacis menekankan kepada pembebanan hukuman (punishment) sebagai alasan pembenar adanya perang. ${ }^{28}$

\section{Ius ad Bellum}

Ius ad bellum adalah ajaran yang menyatakan bahwa perang adalah suatu tindakan yang sah apabila didasarkan kepada alasan-alasan yang benar. Untuk memahami doktrin ini perlu dibedakan terlebih dahulu antara perang internasional (international wars) dan perang sipil (revolution). Terkait dengan perang internasional Grotius mengikuti tradisi perang yang sah (just war) dengan menolak pasifisme (pacifism) dan mensyaratkan alasan yang sah untuk melakukan perang. Dalam karya-karya awalnya, Grotius menekankan mengenai kebolehan perang dan menentang pasifisme.

Atas dasar itu Grotius kemudian memformulasikan alasan perang yang sah dalam terma negatif yaitu, perang yang tidak melanggar hak-hak bangsa lain diperbolehkan (a war that does not infringe on the rights of other nations is permissible). Hal ini akan menciptakan kesan bahwa hukum asal mengenai perang (default rule) adalah boleh. Namun dalam karya-karya berikutnya kesan pemaknaan seperti ini tidak sepenuhnya benar, karena kemudian Grotius membedakan pengertian antara alasan (reason) dan motif (motive). Reason adalah alasan yang benar dan berbasis moral, sedangkan motive bermakna alasan yang

28 David J. Bederman, "Reception of the Classical Tradition in International Law: Grotius' De Jure Belli ac Pacis," Grotiana, Vol. 16/17, 1995/1996, hlm 7. 
berbasis kehati-hatian dan kearifan (prudential reason). Menurut Grotius, perang yang sah adalah perang yang didasarkan kepada alasan yang sah (reason, just cause).

Dalam praktik, kebanyakan negara melakukan perang dengan menggabungkan antara motive dan reason yang kemudian meletakkan pemaknaan perang sebagai sesuatu yang dapat dilakukan apabila merupakan reaksi terhadap kerugian yang dideritanya. ${ }^{29}$ Pemaknaan seperti ini akan berbeda dengan pendapat Grotius sebelumnya yang mengatakan bahwa hukum asal perang adalah boleh. Dalam pemaknaan yang baru akan berbunyi, perang dengan alasan selain kesalahan yang dibenarkan tidak diperbolehkan (wars for reasons other than righting wrongs are disallowed). Pemaknaan ini kemudian dikonfirmasi dengan pendapat Grotius berikutnya mengenai alasan pembenar untuk adanya perang yaitu, self-defense, the recovery of what is ours, dan punishment. Dalam konteks ini Grotius bukan hanya tidak memperbolehkan alasan kepentingan nasional (self-interest) seperti perluasan wilayah ataupun kemuliaan negara, tapi juga menolak dilema keamanan (security dillema) sebagai alasan pembenar, misalnya karena kekhawatiran serangan dari negara tetangga.

Grotius menetapkan standar yang tinggi untuk perang dengan alasan mempertahankan diri (self-defense), yaitu harus dilakukan untuk mempertahankan diri terhadap serangan yang tidak sah (unjust attack). Grotius memberikan peringatan serius agar tidak melakukan perang dengan alasan yang bersifat khayalan terhadap serangan musuh (self-delusion). Pandangan Grotius ini sangat visioner dalam konteks hukum internasional modern saat ini. Namun, merupakan suatu yang keliru menyamakan pandangan Grotius dengan aturan hukum internasional saat ini. Dalam pandangan Grotius, adanya satu alasan pembenar dapat dijadikan alasan untuk dibolehkannya perang, tapi hal ini berbeda dengan hukum internasional saat ini yang melarang perang apabila alasan tersebut tidak merupakan sebuah penyerangan bersenjata (armed attack).

\section{Ius in Bello}

Berbeda dengan ius ad bellum yang berbicara mengenai alasan kebolehan perang, ius in bello adalah ajaran tentang tata cara perang atau mungkin juga dapat dimaknai sebagai hukum tentang perang (the law of war). Pemikiran Grotius mengenai konsep ini sangat penting mengingat pada saat itu hukum perang baru pada tahap pembentukan (formative period). Grotius mempertahankan urgensi moralitas perang terhadap adagium inter arma enim silent leges (dalam konflik bersenjata/perang, hukum tidak berlaku/diam). Perang tidak boleh dilakukan tanpa ikatan ketaatan terhadap hukum dan keadilan.

29 David Luban, "War as Punishment," Philosophy and Public Affairs, Vol. 39, 2012, hlm. 306. 
Pendekatan Grotius agak tidak biasa, karena dia mengaitkannya dengan ajaran hukum alam yang mendalilkan; kita diijinkan untuk membunuh musuh karena musuh mengancam kita. Kita juga dapat mengambil kekayaannya, sepanjang diperlukan untuk alasan keamanan. Hak untuk menggunakan kekerasan senjata termasuk juga hak untuk menghukum, tetapi harus dalam batas-batas keadilan. Kita tidak diijinkan untuk membunuh atau menghancurkan aset musuh yang dilakukan secara tidak proporsional dengan kerusakan yang kita terima. Pemikiran Grotius ini sangat rasional dan pada umumnya diikuti oleh hukum internasional modern. Yang jelas, Grotius percaya bahwa praktik perang jauh melampaui standar keadilan. Jika demikian, rekomendasinya adalah desakan yang ditujukan kepada para penguasa untuk memanusiawikan perang, dan bukan menghadirkan filsafat perang yang lengkap.

Atip Latipulhayat 